\title{
Nyitott hasi aortaaneurysma-mütétek patkóvese fennállása esetén
}

\author{
Bálint Sándor Zsolt dr. ${ }^{1}$ - Mihály Zsuzsanna dr. ${ }^{2}$ \\ Oláh Zoltán dr. ${ }^{2}$ - Sótonyi Péter dr. ${ }^{2}$
}

\author{
${ }^{1}$ Maros Megyei Klinikai Sürgősségi Kórház, Érsebészeti Osztály, Marosvásárhely \\ ${ }^{2}$ Semmelweis Egyetem, Városmajori Szív- és Érgyógyászati Klinika, Érsebészeti és Endovaszkuláris Tanszék, \\ Budapest
}

\begin{abstract}
A patkóvese a vese leggyakrabban előforduló fejlődési rendellenességeinek egyike. Hasi aortaaneurysmával való együttes előfordulása kifejezetten ritka (a hasi aortaaneurysmás esetek 0,12\%-a). Az első esetben egy 64 éves férfi akut alsó végtagi panaszokkal került felvételre. A CT-angiográfia patkóvesét és thrombotizált infrarenalis aortaaneurysmát igazolt. Az akut mútét során a hasi aortaaneurysma resectióját és aortobifemoralis bypassmútétet végeztünk a patkóvese ishmusának megtartásával. A második esetben hasi panaszokat okozó, mindkét arteria iliaca communisra ráterjedő infrarenalis aortaaneurysma esetén végeztünk aortobiiliacalis rekonstrukciót. Az aneurysma előtt elhelyezkedő isthmus tervezetten szétválasztásra került, a poláris veseartériát visszaültettük. A tünetes hasi aortaaneurysma abszolút mütéti indikációt képez. A preoperatív CT- vagy MR-angiográfia kulcsfontosságú mind a mütéti indikáció felállítása, mind pedig a mútét megtervezése szempontjából. A beavatkozás előtt pontos képet kell kapnia az érsebésznek az aorta anatómiája mellett a patkóvese vérellátásáról és a húgyúti rendszerról. Az érsebészeti rekonstrukció esetén a transperitonealis feltárás - fő́leg akut mútét esetén - több előnnyel rendelkezik, mint a retroperitonealis feltárás.

Orv Hetil. 2020; 161(46): 1966-1971.
\end{abstract}

Kulcsszavak: aortaaneurysma, aortaelzáródás, patkóvese, érsebészet, aortobifemoralis bypass

\section{Open repair of abdominal aortic aneurysms in patients with horseshoe kidney}

Horseshoe kidney is one of the most common congenital disorders of the kidney. The simultaneous incidence of horseshoe kidney and abdominal aneurysm is very low ( $0.12 \%$ of all cases of abdominal aortic aneurysm). In the first case, a 64-year-old male patient was admitted with acute lower limb ischaemia. CT-angiography revealed an occluded aortic aneurysm. During the emergency operation, the abdominal aneurysm was resected and an aortobifemoral bypass procedure was performed sparing the kidney's isthmus. In the second case, the abdominal complaints were caused by an infrarenal abdominal aneurysm that involved both common iliac arteries. Aortobiiliac reconstruction was performed with planned separation of the kidney isthmus and reimplantation of the accessory renal artery. Symptomatic abdominal aortic aneurysm is an urgent indication for reconstruction. The preoperative CT- or MR-angiography play a key role in the indication and planning of the reconstruction. It is highly important for the vascular surgeon to have a clear picture of the blood supply of the horseshoe kidney and the urinary tract along with the anatomy of the aorta before the operation. The transperitoneal approach has several advantages over the retroperitoneal approach during vascular reconstruction surgery.

Keywords: abdominal aortic aneurysm, aortic occlusion, horseshoe kidney, aortobifemoral bypass

Bálint SZs, Mihály Zs, Oláh Z, Sótonyi P. [Open repair of abdominal aortic aneurysms in patients with horseshoe kidney]. Orv Hetil. 2020; 161(46): 1966-1971.

(Beérkezett: 2020. április 20.; elfogadva: 2020. június 6.)

\section{Rövidítések}

$\mathrm{CT}=($ computed tomography) számítógépes tomográfia; CTA $=($ CT-angiography) CT-angiográfia; eGFR $=($ estimated glomerulus filtration rate) becsült glomerulusfiltrációs ráta;
EVAR $=($ endovascular aneurysm repair $)$ endovascularis aortarekonstrukció; $\mathrm{MR}=$ (magnetic resonance) mágneses rezonancia NA $=$ noradrenalin; $\mathrm{VAC}=($ vacuum-assisted closure $)$ vákuumasszisztált sebzárás 
A patkóvese a vese leggyakrabban előforduló veleszületett fejlődési rendellenességeinek egyike. Előfordulása kevesebb mint $0,25 \%$ az átlagpopulációban, férfiakban kétszer gyakoribb. A patkóvese a vesetelepek embrionális fejlődése és proximalis vándorlása során alakul ki, a két vesepólus középvonali összeolvadásával. Az isthmust általában kötőszövet alkotja, de veseparenchyma, ritka esetben veseüregrendszer is fejlödhet benne. Az esetek döntő többségében az isthmus a két alsó vesepólust köti össze, de ismert a két felső pólust összekötő változat is. A patkóvese leggyakoribb elhelyezkedése a 3-as és az 5-ös lumbális csigolya (terminális aorta) szintjén található. Az isthmus jelenléte akadályozza a vesék elfordulását, ezáltal mediálisan elhelyezkedő alsó vesepólusokat, előrenéző vesemedencéket, valamint magasan eredő uretereket okoz. A fúzió lehet szimmetrikus vagy aszimmetrikus - amennyiben az egyik vese hypoplasticus vagy alacsonyabban helyezkedik el. Az isthmus rendszerint az aorta előtt helyezkedik el, de az irodalomban leírtak az aorta mögött található ritka esetet is. Az ureterek rendszerint az isthmus előtt futnak, viszont ismert az isthmus mögött elhelyezkedő változat is. Vérellátása jelentős változatosságot mutat. A veseartériák eredhetnek az aortából, az arteria iliaca communisokból vagy akár az arteria mesenterica inferiorból. Eisendrath és mtsai hat csoportba osztályozták a vérellátás sajátosságait a veseartériák eredése és száma szerint (1. táblázat) [1, 2].

Aneurysmának nevezzük az adott érszakaszon elhelyezkedő értágulatot, amelynek átmérője legalább 50\%kal meghaladja a normális szakasz átmérőjét. A valódi aneurysma falában valamennyi érfalréteg fellelhető [3]. $\mathrm{Az}$ aneurysmák az érrendszer bármely szakaszán előfordulnak. Az aortaaneurysmák közül az infrarenalis aortaaneurysma messze a leggyakoribb. 65 év felett a kaukázusi népcsoport 4,7\%-át, míg az ázsiai népcsoport 0,45\%-át érinti [4]. A legtöbbször csak más vizsgálat mellékleleteként kerülnek felfedezésre. A tünetek megjelenését alarmírozó jelnek tekintjük, amely sürgető beavatkozást tesz szükségessé. A tünetmentes, férfiaknál 55 , nőknél $50 \mathrm{~mm}$ feletti maximális átmérőjü hasi aor-

1. táblázat |A patkóvese vérellátása Eisendrath és mtsai szerint [2]

\begin{tabular}{|c|c|c|}
\hline Típus & $\begin{array}{l}\text { Elöfordulási } \\
\text { arány }\end{array}$ & Anatómiai variáció a patkóvese ellátásában \\
\hline 1-es típus & $20 \%$ & Egy veseartéria mindkét oldalon \\
\hline 2-es típus & $30 \%$ & $\begin{array}{l}\text { Egy veseartéria mindkét oldalon és egy } \\
\text { isthmust ellátó ág az aortából }\end{array}$ \\
\hline 3-as típus & $15 \%$ & $\begin{array}{l}\text { Két veseartéria mindkét oldalon és egy } \\
\text { isthmust ellátó ág az aortából }\end{array}$ \\
\hline 4-es típus & $15 \%$ & $\begin{array}{l}\text { Két veseartéria mindkét oldalon és egy } \\
\text { vagy több, isthmust ellátó ág az arteria } \\
\text { iliacából }\end{array}$ \\
\hline 5-ös típus & $20 \%$ & $\begin{array}{l}\text { Az aortából, az arteria mesentericából és } \\
\text { az arteria iliacából eredő többszörös } \\
\text { veseartériák }\end{array}$ \\
\hline
\end{tabular}

taaneurysma mútéti indikációt képez a jelentős rupturarizikó miatt. A rupturált hasi aortaaneurysma-mútétek mortalitása pedig még kórházi körülmények között is közel $50 \%[4,5]$.

Sem az infrarenalis aortaaneurysma, sem a patkóvese nem sorolható a gyakori megbetegedések közé, de együttes előfordulásuk kivételesen ritkának tekinthető, a hasi aortaaneurysma-esetek 0,12\%-a. Az aorta elött elhelyezkedő isthmus, a gyakran atípusosan eredő artériák és vénák, valamint a szokatlan lefutású ureterek jelenléte jelentősen megnehezíti a feltárást, a kirekesztést, az érprotézis pozicionálását és felvarrását is [6].

A továbbiakban két esetet mutatunk be, amelyeknél infrarenalis hasi aortaaneurysma és patkóvese együttes fennállása esetén végeztünk aortobiiliacalis, illetve aortobifemuralis rekonstrukciót.

\section{Esetismertetés}

\section{Az elsö beteg}

Az első esetben egy 64 éves férfi beteg akutan került felvételre hirtelen kialakult kétoldali, 5 méteres dysbasia, fartájéki fájdalom és zsibbadás, valamint mindkét oldalon észlelt végtaggyengeség miatt. Anamnézisében hypertonia, gastrooesophagealis refluxbetegség és dohányzás szerepelt. A fizikális vizsgálat során hưvösebb alsó végtagokat, valamint mindkét alsó végtagon hiányzó pulzust észleltünk. Az elvégzett CTA az infrarenalis aorta $44 \mathrm{~mm}$ legnagyobb átmérőjü fusiformis aneurysmájának thrombosisát mutatta az arteria mesenterica inferior eredése alatt, mindkét arteria iliaca communis elzáródásával. Az iliaca communisok distalis szakaszai jól visszatelődtek az oszlások szintjén. A femoralis communis és a distalis érpálya mindkét oldalon kielégítően telődött. A zsigeri verőerek szájadéka szabad volt. Mellékleletként a vizsgálat az aorta oszlása előtt elhelyezkedő, szeparált vérellátású és két pyelonnal rendelkező szimmetrikus patkóvesét írt le (1. ábra). Mindkét vese vérellátását egy-egy, normális pozícióban eredő veseartéria (Eisendrath-féle l-es típus) biztosította. A hozott laboreredményekben korrigálandó vesefunkció-eltérés nem volt (eGFR: 114,7 ml/min/1,73 $\mathrm{m}^{2}$, kreatinin: 48 umol/l).

Az akut mútét során a patkóvese mobilizációját követően a hasi aortaaneurysma resectióját és aortobifemoralis bypassmütétet végeztünk Dacron bifurcatiós érprotézist használva. A graftot az infreranalis aortára, az arteria mesenterica inferiortól distalisan vég a véghez varrtuk, a patkóvese isthmusa mögött vezettük el. A bal oldalon dezobliteráltuk az arteria femoralis communist, a distalis intima lépcsőt leszegtük, jó be- és kiáramlás mellett vég az oldalhoz distalis anastomosisokat készítettünk (2. ábra).

A posztoperatív időszakban a végtagok kimelegedtek. A jobb oldalon az arteria tibialis posterior, a bal oldalon az arteria dorsalis pedis tapinthatóvá vált. Légzési elégte- 


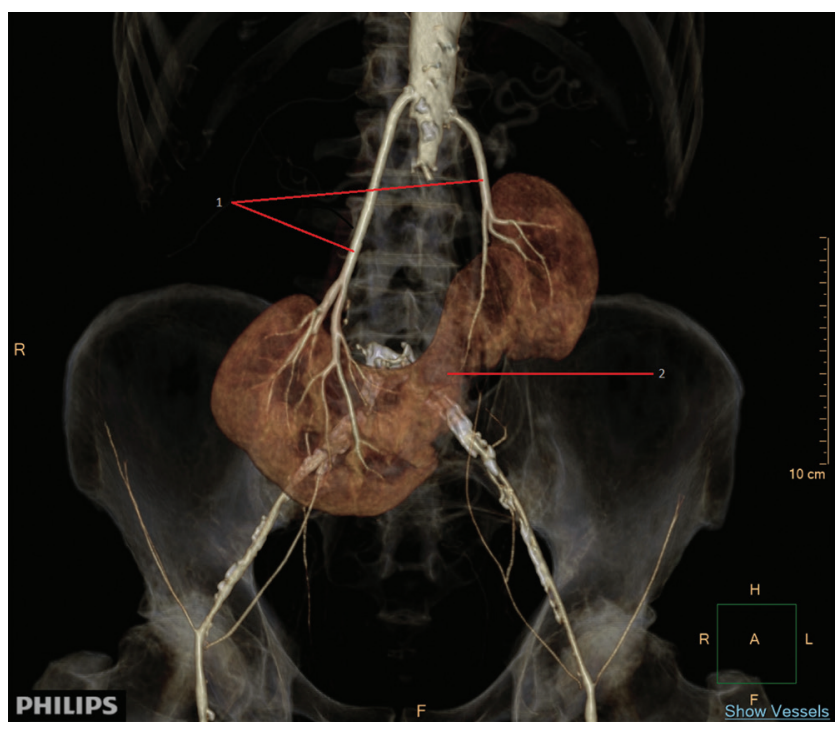

1. ábra $\mid$ Az első eset mútét előtti 3D CTA-képe. 1: arteria renalis; 2 : isthmus

3D = háromdimenziós; CTA = számítógépes tomográfiás angiográfia

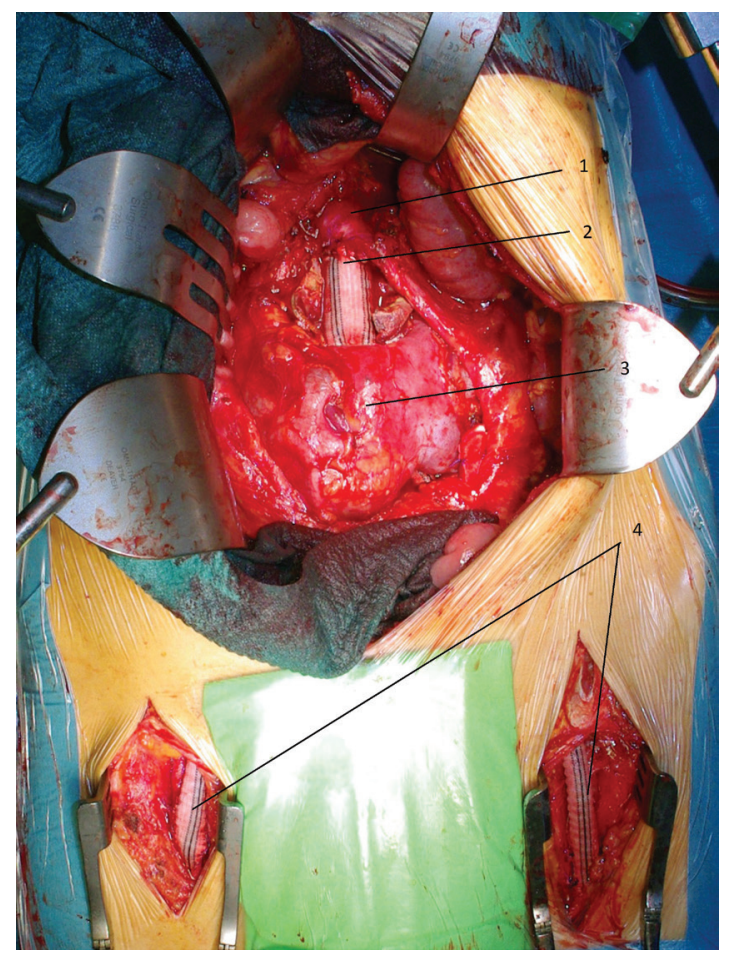

2. ábra

Az első eset mútéti képe rekonstrukció után. 1 : bal vena renalis
2 : az aortobifemoralis bypass proximalis anastomosisa; 3 : patkóvese (isthmus); $4:$ az aortobifemoralis bypass distalis graftszárai

lenséget okozó pneumonia miatt a páciens a mútét utáni 2. napon ismét gépi lélegeztetésre és vazopresszoros keringéstámogatásra szorult. A kombinált antibiotikum(meropenem + gentamicin) és antimikotikum (flukonazol)-kezelés mellett láztalanná vált. A jobb tüdőfélben leírt infiltrátum jelentősen regrediált, a mútét utáni 7. napon a beteget extubálták. A bélmúködés fokozatosan rendeződött, a vesefunkció mindvégig kielégítő volt. Anaemiáját 2 egység választott vörösvértest-koncentrátum transzfúziójával rendeztük. Az intenzív terápiás kezelése alatt kialakult átmeneti zavartság fokozatosan javult.

Ezt követően kielégítő általános állapotban, gyógyuló sebekkel otthonába bocsátottuk. A kontrollvizsgálatok során a beteg mindvégig panaszmentes volt, járástávolsága korlátlan, vesefunkciós értékei jelenleg is a normáltartományban vannak.

\section{A második beteg}

Második betegünk, egy 70 éves férfi, hasi panaszokat okozó, nagy méretû infrarenalis hasi aortaaneurysma mütéti megoldása miatt került sürgető felvételre. Kórelőzményében régóta ismert magas vérnyomás, hyperlipoproteinaemia, cholecystectomia és pajzsmirigyhormon-szubsztitúciós kezelés szerepelt. A CTA-felvételen a veseartériák eredése alatt kezdődő, $8 \mathrm{~cm}$ átmérőjü, mindkét arteria iliaca communisra ráterjedő aortaaneurysma ábrázolódott. A jobb oldalon a normálisan elhelyezkedő veseartéria $(3,7 \mathrm{~mm})$ mellett a CT-vizsgálat az aneurysmából eredő erős poláris ágat $(3,5 \mathrm{~mm})$ írt le, amely a jobb vesefelet látta el (Eisendrath-féle 2-es típus) (3. ábra). A további kivizsgálások során mérsékelten beszúkült vesefunkcióra (kreatinin: $160 \mu \mathrm{mol} / \mathrm{l}$; eGFR: 36 $\mathrm{ml} / \mathrm{min} / 1,73 \mathrm{~m}^{2}$ ), valamint a bal arteria carotis interna 50\%-os szúkületére derült fény.

A mútét során mobilizáltuk a veseállományt, majd az aorta felett a zömmel kötőszövetes isthmust kettéválasztottuk. A végeket tefloncsíkkal erősített parenchymaölté-

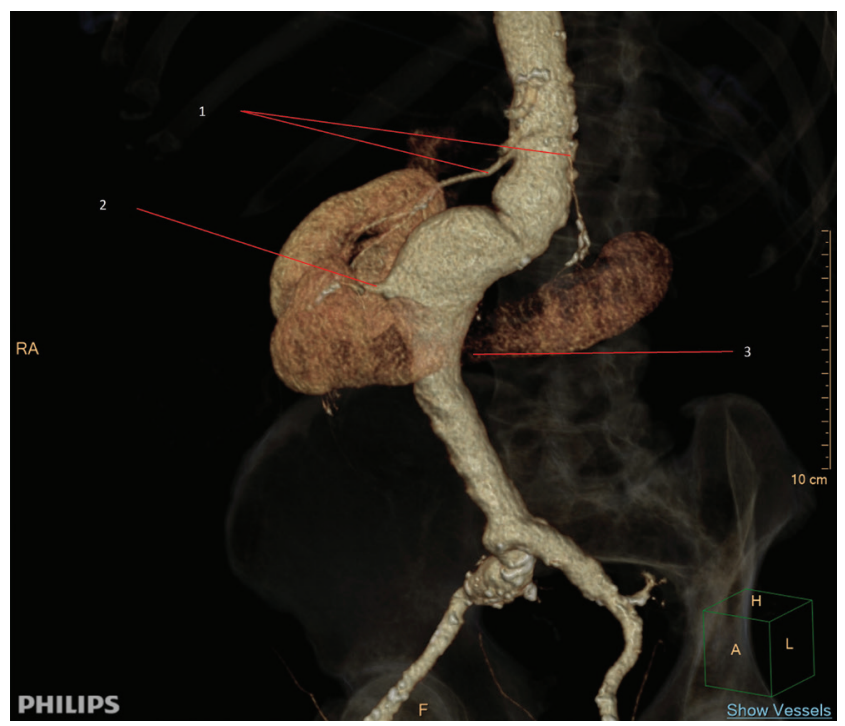

3. ábra

A második eset mútét előtti 3D CTA-képe. 1: jobb és bal arteria renalis; 2 : aneurysmazsákból eredő poláris arteria renalis; 3 : szeparált isthmus

3D = háromdimenziós; CTA = számítógépes tomográfiás angio gráfia 
sekkel elvarrtuk. Az aneurysma megnyitása után infrarenalisan alakítottuk ki a vég a véghez típusú anastomosist. A graftszárakat mindkét oldalon az arteria iliaca communis oszlására varrtuk, szintén vég a véghez anastomosissal. A patkóvese jobb oldalához futó erôs poláris ágat visszaültettük a graftba.

A mútétet követően a beteget intenzív terápiás osztályon helyeztük el, ahol rövid időn belül problémamentesen extubálták. Alacsony vérnyomás miatt átmenetileg volumenpótlást és alacsony dózisú NA-keringéstámogatást igényelt. Vizeletürítése forszírozott diuresis mellett kielégítố volt. Vesefunkciós paraméterei az 5. posztoperatív napon tetőztek (kreatinin: $507 \mu \mathrm{mol} / \mathrm{l}$, karbamid: $22 \mathrm{mmol} / 1$, eGFR: $\left.9,1 \mathrm{ml} / \mathrm{min} / 1,73 \mathrm{~m}^{2}\right)$, majd javulni kezdtek, az akut dialíziskezelésnek javallata nem volt. Posztoperatív paralitikus béltevékenysége prokinetikum és laxatívum adása mellett rendeződött. Az alsó végtagokban keringészavart nem észleltünk. Subfebrilitas, emelkedő gyulladásos paraméterek és pneumonia klinikai és radiológiai képe miatt empirikus antibiotikum(piperacillin + tazobaktám) kezelésben részesült.

Ezt követôen a páciens stabil vitális paraméterekkel, nazális oxigénterápia mellett a mútét utáni 7 . napon ke-

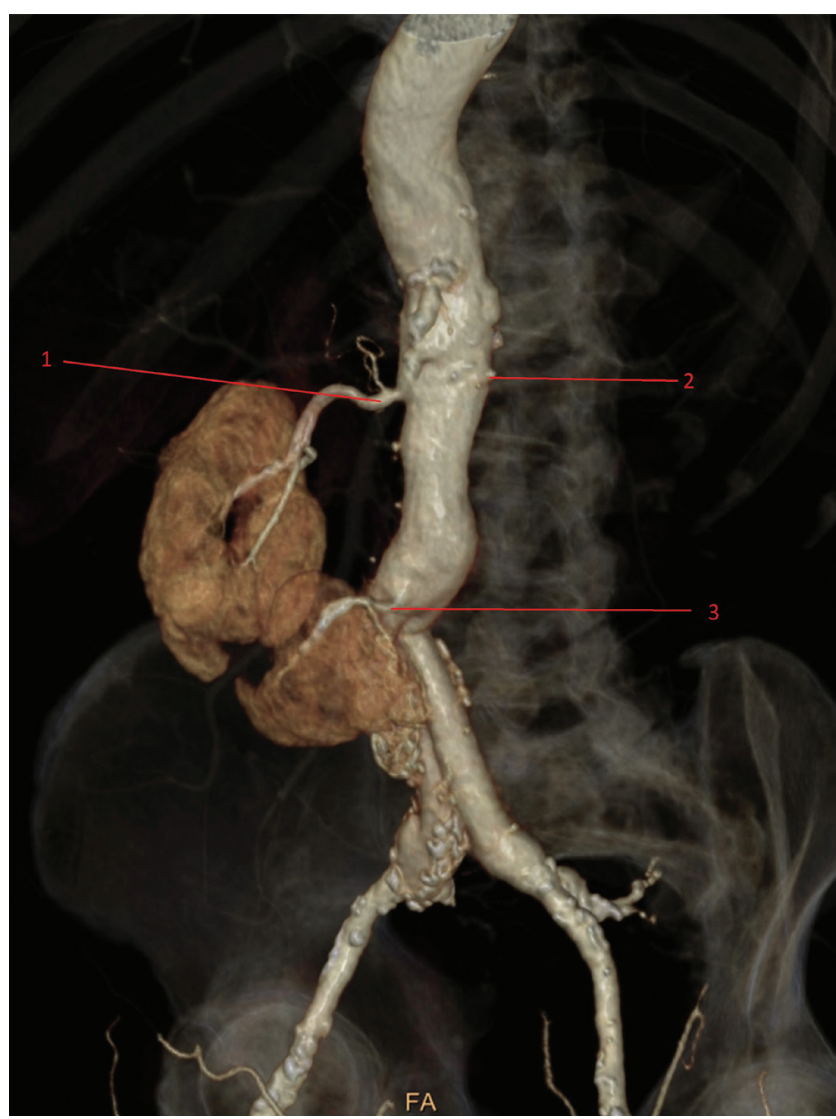

4. ábra

A második eset kontroll 3D CTA-képe. 1: jobb arteria renalis; 2 elzáródott bal arteria renalis; 3: reimplantált poláris veseartéria

3D = háromdimenziós; CTA = számítógépes tomográfiás angiográfia rült területi belgyógyászati osztályra, ahonnan a későbbiekben otthonába bocsátották. Elhúzódó sebgyógyulás miatt hasi sebén VAC-kezelést alkalmaztunk. A kontrollvizsgálatokon a beteg panaszmentes volt (4. ábra). A beteg általános állapota a kontrollok alapján mindvégig kielégítő volt. Járástávolsága, ismert femoropoplitealis occlusiója mellett, változatlanul 300 méter maradt, vesefunkciós értékei továbbra is a $30-40 \mathrm{l} / \mathrm{min} / 1,73 \mathrm{~m}^{2}$ tartományban voltak.

\section{Megbeszélés}

A tünetes hasi aortaaneurysma abszolút mútéti indikációt képez. Sürgető mútéti megoldása elengedhetetlen. Az anatómiai viszonyok, a rizikófaktorok és a rendelkezésre álló lehetőségek alapján kell mérlegelni a mútéti megoldás módját [7]. Az általunk ismertetett első esetben az aneurysma elzáródása nem tette lehetővé az endovascularis aortarekonstrukció elvégzését (endovascular aneurysm repair - EVAR). A második esetben mind a rövid aneurysmanyak (a veseartériák alatti ép aortaszakasz, ún. „landing zóna”), mind az aneurysma falából eredő, 3,7 mm átmérójü poláris artéria jelenléte az EVAR elvégzése ellen szólt. A jelenlegi európai ajánlás alapján a $3 \mathrm{~mm}$ nél nagyobb átmérőjü, illetve a vese parenchymájának egyharmadánál nagyobb területet ellátó artériák megtartása javasolt EVAR esetén [8]. Hasi aortaaneurysma-mútét esetén mind a transperitonealis (medián vagy haránt), mind a retroperitonealis feltárás alkalmazható. A fent ismertetett eseteinknél mindkét alkalommal medián laparotomiát alkalmaztunk, figyelembe véve előnyeit: jó hozzáférés a hasüregi szervekhez, jó lehetőséget ad mindkét arteria iliaca ellátására, a veseartériák és ureterek anatómiai sajátosságainak pontos felderítésére. Fő hátránya a bal retroperitonealis feltárással szemben patkóvese esetén az, hogy az isthmus megtartása és az abberánsan eredő veseartériák reimplantációja nehézkesebb $[8,9]$.

$\mathrm{Az}$ aneurysmamútét során a sebész három fơ nehézségbe ütközhet. Az első a vérzés uralása. A proximalis kirekesztés helyét - az aneurysma méretétől és a veseartériák anatómiájától függően - a veseartériák alatt vagy felett (akár supracoeliacalisan) is kialakíthatjuk. Distalisan a kirekesztés rendszerint megvalósítható a két arteria iliaca külön-külön való lefogásával vagy akár occlusiós ballonkatéterekkel az aneurysmazsák megnyitása után. Az utóbbi esetében az ureterek sérülésének veszélye kisebb [9].

A következő nehézséget a veséket összekötő isthmus jelenléte okozza. A már említett transperitonealis feltárás hátránya, hogy az isthmus megnehezíti a terminális aortához való hozzáférést. Szétválasztása akut mưtét esetén lehet indokolt, vagy abban az esetben, amikor döntően kötőszövet alkotja (15\%) [1]. Átvágását követheti ischaemia, vérzés, vizeletbeszúrődés a retroperitoneumba (amennyiben nincs megfelelően ellátva a metszésvonal), fistulaképződés, szepszis és veseelégtelenség. Ezért törekedni kell az isthmus mobilizálására és megtartására 
[10]. Első páciensünk esetében az isthmus az aneurysma nyakától caudalisan helyezkedett el, így lehetóséget adott a proximalis anastomosis kialakítására és a graft mögötte való elvezetésére. Ezért nem került sor az átvágására. A második páciens esetében az isthmus átvágásra került, mert elfedte az anastomosis kialakítására ideális infrarenalis aortaszakaszt, továbbá akadályozta a poláris artéria eredéséhez való hozzáférést, ami az ér későbbiekben elvégzett visszaültetése szempontjából kulcsfontosságú volt. A CT-felvételek alapján a két teljesen elkülönült vérellátású vesefelet egymástól szeparált üregrendszerből álló isthmus kötötte össze, ezért szétválasztása technikailag kivitelezhető volt. A mútét után ezzel kapcsolatos szövődmény nem alakult ki: a vesefunkció paraméterei az 5. napon tetőztek, majd a mútét elötti értékekre csökkentek. A második esetben a patkóvese szétválasztását nem lehetett elkerülni azért, mert az aneurysma nyitott rekonstrukcióját és a poláris ág visszaültetését el kellett végezni. Az aneurysma ellátása nem volt elvégezhető endovascularisan a proximalis landing zóna alkalmatlansága (rövid, kónikus nyak, 'shaggy' aorta) és az $5 \mathrm{~mm}$-t el nem éró poláris ág miatt $(5 \mathrm{~mm}$ alatti artéria nem alkalmas fenesztrált graft beültetésére).

A harmadik nehézséget a poláris veseartériák jelentik. A patkóvese vérellátására jelenleg a már említett Eisendrath-féle osztályozás a legelfogadottabb. A jelenlegi ajánlások szerint minden, 3 mm-nél nagyobb átmérőjü poláris artériát meg kell tartani vagy vissza kell ültetni [4]. Ez különösen fontos már meglévő veseelégtelenség esetén (2. beteg) [9].

Elhúzódó suprarenalis kirekesztés (>30 perc) vagy poláris veseartéria reimplantációja esetén szükség van a vese ischaemia elleni védelmére. Ez megvalósítható a kirekesztés időnkénti rövid felengedésével vagy a veseparenchyma lokális hütésével. Irodalmi adatok szerint, ha a kezdeti vesefunkció jó, és az ischaemiás idő nem haladja meg a 30 percet, a páciensek $60 \%$-ánál nem alakul ki akut veseelégtelenség. Akiknél kialakul, azoknak az 55\%-ánál lábadozás alatt rendeződik. Ha a kirekesztés 30 percnél tovább tart, vagy ha kezdeti beszúküult vesefunkció áll fenn, a veseartériák krisztalloid oldattal való átöblítése javasolt. Ez szignifikánsan csökkenti a szövődményes veseelégtelenség kialakulását [11]. Esetünkben mindkét páciensnél infrarenalis kirekesztést alkalmaztunk, ezért nem volt szükség a vese védelmére.

\section{Következtetés}

A Városmajori Szív- és Érgyógyászati Klinikán előfordult két esetet mutattunk be, amelyeknél infrarenalis hasi aortaaneurysma és patkóvese együttes fennállása miatt végeztünk aortobiiliacalis, illetve aortobifemoralis rekonstrukciót. Mind a patkóvese, mind az infrarenalis aortaaneurysma előfordulása ritka jelenség, együttes előfordulásuk kivételes. A nagy méretű, panaszt okozó hasi aortaaneurysma és az akut aneurysmaelzáródás is sürgető mütéti indikációt képez. Amennyiben a beteg alacso- nyabb rizikócsoportba sorolható, vagy az EVAR elvégzése technikailag nem lehetséges, nyitott mútéti megoldás javasolt. Az egyik esetben a patkóvese nem került szétválasztásra, mert elhelyezkedése lehetővé tette a proximalis anastomosis kialakítását és a graft mögötte való elvezetését. A másik esetben a nagy méretü aneurysma előtt elhelyezkedő patkóvese tervezetten szétválasztásra került, emellett a jobb poláris veseartéria visszaültetésére is szükség volt.

A preoperatív CT- vagy MR-angiográfia kulcsfontosságú mind a mûtéti indikáció, mind a műtét megtervezése szempontjából. A beavatkozás előtt pontos képet kell kapnia az érsebésznek az aorta anatómiája mellett a patkóvese vérellátásáról és a húgyúti rendszerről. Vesetranszplantáció után végzett aortaaneurysma rekonstrukciós mútétről tudósító esetismertetés során is a preoperatív CT angiográfiás képalkotó vizsgálat kulcsszerepet játszott a sikeres mütét megtervezésében [12], az általunk bemutatott esetekhez hasonlóan.

Az érsebészeti rekonstrukció kapcsán a transperitonealis feltárás a retroperitonealis feltárással szemben - főleg akut mútét esetén - több elönnyel rendelkezik. A proximalis és a distalis lefogások kontrollja, a mindkét oldalt érintő patkóvese mobilizációja és a poláris veseartériák reimplantációja is könnyebb ebből a behatolásból. A 3 mm-nél nagyobb poláris veseartériák megtartása ajánlott. Lehetőség szerint az isthmus mobilizálása és intakt állapotban megtartása ajánlott.

Anyagi támogatás: A közlemény megírása anyagi támogatásban nem részesült.

Szerzői munkamegosztás: S. P.: Operatőr, a beteg klinikai követése, ellátása, az adatok és a leletek dokumentálása. O. Z.: Asszisztens. S. P., B. S. Zs., M. Zs.: Az adatok és a leletek feldolgozása, a kézirat megszövegezése. A cikk végleges változatát valamennyi szerző elolvasta és jóváhagyta.

Érdekeltségek: A szerzőknek nincsenek érdekeltségeik.

\section{Irodalom}

[1] Schiappacasse G, Aguirre J, Soffia P, et al. CT findings of the main pathological conditions associated with horseshoe kidneys. Br J Radiol. 2015; 88: 20140456.

[2] Eisendrath DN, Phifer FM, Culver HB. Horseshoe kidney. Ann Surg. 1925; 82: 735-764.

[3] Horváth ÖP, Kiss J. Littmann's surgical techniques. [Littmann sebészeti mútéttan.] Medicina Könyvkiadó, Budapest, 2014. [Hungarian]

[4] Kovács H, Fehérvári M, Forgó B, et al. Early and late mortality and morbidity of elective infrarenal aortic aneurysm repair. [Electiv infrarenalis aortaaneurysma sebészi kezelésének korai és késői mortalitása és morbiditása.] Magy Seb. 2014; 67: 297303. [Hungarian]

[5] Grant MW, Thomson IA, van Rij AM, et al. In-hospital mortality of ruptured abdominal aortic aneurysm. ANZ J Surg. 2008; 78: 698-704. 
[6] Sachsamanis G, Charisis N, Maltezos K, et al. Management and therapeutic options for abdominal aortic aneurysm coexistent with horseshoe kidney. J Vasc Surg. 2019; 69: 1257-1267.

[7] Sidawy AN, Perler BA. Rutherford's vascular surgery and endovascular therapy. Elsevier, Philadelphia, PA, 2019.

[8] Wanhainen A, Verzini F, Van Herzeele I, et al. Clinical practice guidelines on the management of abdominal aorto-iliac artery aneurysms. Eur J Vasc Endovasc Surg. 2018; 57: 8-93.

[9] Davidovic LB, Markovic M, Kostic D, et al. Open repair of ruptured abdominal aortic aneurysm with associated horseshoe kidney. Int Angiol. 2018; 37: 471-478.

[10] Canova G, Masini R, Santoro E, et al. Surgical treatment of abdominal aortic aneurysm in association with horseshoe kidney. Three case reports and a review of techniqe. Tex Heart Inst J. 1998; 25: 206-210
[11] Svensson LG, Crawford ES, Hess KR, et al. Thoracoabdominal aortic aneurysms associated with celiac, superior mesenteric, and renal artery occlusive disease: methods and analysis of results in 271 patients. J Vasc Surg. 1992; 16: 378-389.

[12] Boros P, Olvasztó S, Litauszky K, et al. Successful treatment of infrarenal aortic aneurysm in the case of a patient after renal transplantation. [Vesetranszplantált beteg infrarenalis aortaaneurysmájának sikeresen kezelt esete.] Orv Hetil. 2019; 160: 14711475. [Hungarian]

(Mihály Zsuzsanna dr., Budapest, Városmajor u. 68., 1122 e-mail: zsuzsannamihaly@gmail.com)

\section{PÁLYÁZAT}

A Prof. Dr. Romics László Akadémikus Emlékére Alapítvány pályázatot hirdet Magyarországon dolgozó, magyar állampolgárságú, 40 éven aluli orvosok és orvosbiológiai kutatással foglalkozó személyek számára. A nyertes pályázó(k) között 500000 Ft alapítványi adomány kerül kiosztásra.

A pályázat célja: a klinikai gyógyítás vagy orvosi tudományos kutatás területén dolgozók kiemelkedő tudományos tevékenységének elismerése.

Előnyt élveznek azok a pályázók, akik az alapítvány névadójának munkásságát folytatva cardiovascularis és anyagcsere-betegségek területéről nyújtanak be pályázatot.

A pályázat benyújtásának határideje: 2021. február 28. (elbírálásának határideje: 2021. április 30.)

A pályázatot a palyazat@romicsalapitvany.hu e-mail címre pdf formátumban kell benyújtani.

A pályázatot természetes személy, saját nevében, magyar nyelven nyújthatja be, a pályázati anyag ábrák nélkül maximum 15000 leütés (karakter) terjedelmü lehet. A pályázathoz mellékelni kell egy rövid szakmai életrajzot a születési év megjelölésével.

A pályázat benyújtását saját kézzel aláírt és dátummal ellátott levélben kell bejelenteni az alapítvány titkárának címezve (a borítékra írandó cím: dr. Dudás Márta, 1461 Budapest, Pf. 62) könyvelt (ajánlott) küldeményben, mert ezen bejelentés alapján válik hitelessé a pályázat. A pályázatot nyomtatott formában nem kell mellékelni.

Az alapítvány adatairól, müködéséről a www.romicsalapitvany.hu honlapon található információ.

A cikk a Creative Commons Attribution 4.0 International License (https://creativecommons.org/licenses/by/4.0/) feltételei szerint publikált Open Access közlemény, melynek szellemében a cikk bármilyen médiumban szabadon felhasználható, megosztható és újraközölhető, feltéve, hogy az eredeti szerző és a közlés helye, illetve a CC License linkje és az esetlegesen végrehajtott módosítások feltüntetésre kerülnek. (SID_1) 